\title{
Start-ups in entrepreneurial ecosystems: the role of relational capacity
}

\author{
Gaël Gueguen and Servane Delanoë-Gueguen \\ Strategy, Entrepreneurship and Innovation, Toulouse Business School, \\ Midi-Pyrénées, France, and \\ Christian Lechner \\ LUISS Business School, LUISS Guido Carli, Rome, Italy
}

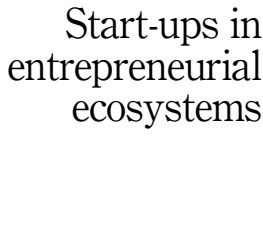

115

Received 3 June 2020 Revised 18 December 2020 2 April 2021 28 July 2021 Accepted 26 September 2021

\begin{abstract}
Purpose - Entrepreneurial ecosystems provide the context for start-ups to access resources. The authors investigate the reliance of start-ups on their entrepreneurial ecosystem and the driving factors behind the proportion of local actors (belonging to their entrepreneurial ecosystem) within their overall set of relationships (their business ecosystem). Recognizing the limited relational capacity of firms, the authors focus on three differentiating firm characteristics: size, age and innovation of firms.

Design/methodology/approach - The authors developed a sample of 163 start-ups located in the entrepreneurial ecosystem of Toulouse, France. The authors investigated the characteristics of their relationship sets using regression analysis.

Findings - The results confirm that age is inversely related to the proportion of a start-up's relationships located in its entrepreneurial ecosystem. More surprisingly, for older start-ups, the authors also highlight the presence of a moderating effect of the start-up's size on the relationship between its degree of innovation and the proportion of its relationships in its entrepreneurial ecosystem: Larger and more innovative start-ups appear to rely more on their local entrepreneurial ecosystem.

Originality/value - This research increases the understanding of the characteristics driving the interactions of start-ups with their entrepreneurial ecosystems by adopting a relational capacity approach. The authors introduce digital methods as an innovative approach for uncovering firms' ecosystems. Finally, from a practical point of view, the research should provide public authorities seeking to promote the link between local resources and the development of innovative start-ups in their regions with interesting insights.
\end{abstract}

Keywords Start-ups, Business ecosystem, Entrepreneurial ecosystem, Relational capacity

Paper type Research paper

\section{Introduction}

The importance of territory, or location, for the competitiveness of entrepreneurial firms has long been acknowledged (Audretsch, 2015; Iacobucci and Perugini, 2021). Entrepreneurial ecosystems represent territories that include institutions that foster the emergence and support of new businesses, bring together individuals with innovation capacity and promote entrepreneurship (Audretsch et al., 2021; Brown and Mason, 2017; Isenberg, 2011; Kansheba and Wald, 2020; Spigel, 2017; Spigel and Harrison, 2018; Voelker, 2012). This concept has proven its relevance in studying start-ups but marked differences exist between various entrepreneurial ecosystems (Autio et al., 2018; Cohen, 2006; Wickham, 2004).

Start-ups' quest for legitimacy (Kuratko et al., 2017) and resources (Harrison et al., 2010; Isenberg, 2011; Sorenson and Stuart, 2001) requires them to interact with other actors

(c) Gaël Gueguen, Servane Delanoë-Gueguen and Christian Lechner. Published by Emerald Publishing Limited. This article is published under the Creative Commons Attribution (CC BY 4.0) licence. Anyone may reproduce, distribute, translate and create derivative works of this article (for both commercial and non-commercial purposes), subject to full attribution to the original publication and authors. The full terms of this licence may be seen at http://creativecommons.org/licences/by/4.0/legalcode
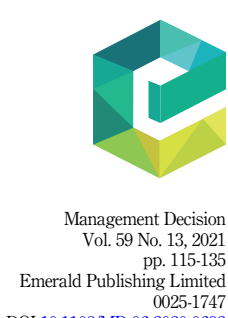
DOI 10.1108/MD-06-2020-0692 
$\mathrm{MD}$

59,13

116

(Autio et al., 2018; Lechner and Dowling, 2003; Nylund and Cohen, 2017; Semrau and Werner, 2014). Interaction among entrepreneurs and with other members of their entrepreneurial ecosystem is thus crucial for firm development (Audretsch et al., 2021; Scheidgen, 2021). Entrepreneurial firms tend to prefer proximate relationships over distant ones (Lechner and Leyronas, 2012). The effectiveness of entrepreneurial ecosystems thus depends on their capacity to provide network access for entrepreneurial firms.

Relational capacity is a primary factor for understanding the networking behavior of entrepreneurial firms and their potential to access resources (Lechner and Dowling, 2003). It represents the ability to engage in, nurture and handle multiple relationships (Dyer and Singh, 1998; Lorenzoni and Lipparini, 1999). As developing new relationships and maintaining existing ones require time and resources, the relational capacity of firms is limited (Lechner and Dowling, 2003). At a system level, differing relational capacity leads to differential network access, which in turn may lead to the suboptimal functioning of an entrepreneurial ecosystem (Stam, 2015). Efficient entrepreneurial ecosystems are characterized by high network density, that is, a maximum number of actors interconnected with each other (Autio et al., 2018; Roundy et al., 2017; Stam, 2015).

Entrepreneurial ecosystems appear to offer a protective environment for start-ups to get operational, build their business ecosystem and eventually survive (Audretsch et al., 2021; Vedula and Kim, 2019). However, the local access to valuable relationships might be limited, which may hinder start-ups' ability to access necessary resources locally (Scheidgen, 2021). Studying how entrepreneurial firms network and what entrepreneurial ecosystems can offer is therefore crucial for understanding the functioning of ecosystems and the potential benefits for firms. While a start-up needs a favorable entrepreneurial ecosystem to develop (Vedula and Kim, 2019), it also needs to build relationships with heterogeneous partners which are not always present nor accessible at the local level. These strategic allies form the start-up's business ecosystem: They bring together communities of organizations, institutions and individuals who interact to contribute to the development and execution of the firm's value proposition (Jacobides et al., 2018; Teece, 2007; Tsou et al., 2019).

If we use an analogy and regard entrepreneurial ecosystems as resembling incubators on a higher, abstract level, then we would expect firms to move out at some point. Thus, the relative importance of entrepreneurial ecosystems for their development would progressively diminish. Moreover, the effect of entrepreneurial ecosystems has been considered in isolation as a closed system, as if the entrepreneurial ecosystem were the primary factor that matters for start-up development. Still, the relative importance for start-ups of relationships with actors from their entrepreneurial ecosystem compared to their overall set of relationships has yet to be considered in a quantitative way (both in terms of proportion and in terms of explanatory factors).

A systematic literature review on entrepreneurial ecosystems indicates that conceptual studies prevail, while empirical research, especially quantitative research, is still scarce (Kansheba and Wald, 2020; Wurth et al., 2021). In other words, Stam's (2015, p. 1,759) call for more "causal depth and evidence base" of the entrepreneurial ecosystem approach remains very topical. In addition, research positioned at the micro level, intending to highlight the specific characteristics of different actors found in entrepreneurial ecosystems, has recently been identified as important for the field to pursue (Audretsch et al., 2021; Iacobucci and Perugini, 2021; Wurth et al., 2021). The idea is to go beyond broad and global approaches to better understand the nature of the interactions present within entrepreneurial ecosystems (Iacobucci and Perugini, 2021) by considering the specificities of the various actors involved (Canovas-Saiz et al., 2021; Gueguen, 2020). The networking behavior of firms is key to understanding both the performance of specific firms and the functioning of the overall entrepreneurial ecosystem. Our research attempts to fill this gap by considering the fundamental characteristics of start-ups and their use of the local entrepreneurial ecosystem. 
As the literature on the topic is still insufficient to understand the link between start-ups characteristics and mobilization of the entrepreneurial ecosystem, our results help promote this contingent approach. In this, we subscribe to the idea that start-ups rely on their entrepreneurial ecosystem in order to gather different resources, whether intangible (legitimacy, knowledge, etc.) or material (financing, infrastructure, etc.). Start-ups' need for resources evolves according to their specificities and their development stage (Scheidgen, 2021). As a result, the benefits that they might draw from their entrepreneurial ecosystems should evolve accordingly.

This leads to our research question: What is the relative importance of the (local) entrepreneurial ecosystem for firms of different age, size and innovation capacity? This question should allow us to derive tentative implications for the role of entrepreneurial ecosystems in firm development, with relational capacity providing one key to understanding (Motoyama and Knowlton, 2017; Roundy et al., 2017). Furthermore, a better understanding of the relationships of start-ups with local actors would contribute to understanding the true contribution and added value of entrepreneurial ecosystems for start-ups, an element insufficiently addressed in the literature (Acs et al., 2017; Audretsch et al., 2021; Scheidgen, 2021).

We specifically investigate which start-ups' characteristics lead them to favor relationships with actors from their entrepreneurial ecosystem compared to other more distant actors. To this end, we focus on a sample of start-ups in the Toulouse region in southwest France. We identify size, age and innovation (Wickham, 2004) as differentiating characteristics among start-ups and analyze their impact on the start-ups' reliance on their entrepreneurial ecosystem. Specifically, we hypothesize that the more a start-up grows in size and age, the more it will reach outside local boundaries (Harrison et al., 2010). We also investigate interaction effects combining the impact of start-ups' size and degree of innovation on the importance of local actors within their relationships. From a practical standpoint, this research therefore aims to provide guidance to policy makers and various actors constituent of entrepreneurial ecosystems for implementing fruitful initiatives to foster entrepreneurship in their area.

In the remainder of the article, we first discuss the theoretical foundations and present our hypotheses and research model. Next, we present our methodology, followed by our results. We then discuss these results and their implications. Finally, we present the limitations of our work and make suggestions for future research.

\section{Theoretical framework and hypotheses development}

The entrepreneurial ecosystem of start-ups as a ground for their business relationships

The entrepreneurial ecosystem corresponds to a set of interconnected entrepreneurial actors (companies, business angels, universities, etc.) and entrepreneurial processes (creation rates, entrepreneurial spirit, etc.) that foster performance within a local entrepreneurial environment (Acs et al., 2017; Brown and Mason, 2017; Isenberg, 2011; Mason and Brown, 2013; Spigel, 2017; Spigel and Harrison, 2018; Stam, 2015; Stam and Van de Ven, 2021; Voelker, 2012). The ecosystem concept emphasizes the role of entrepreneurs and may be seen as an extension of industrial districts, clusters and learning regions (Scaringella and Radziwon, 2018; Wurth et al., 2021). The theories underlying these latter concepts address regional development by combining a reticular logic with a spatial dimension (Lechner, 2017). However, the objective of an entrepreneurial ecosystem is more specific: It is to nurture embryonic firms and foster entrepreneurship (Audretsch et al., 2021; Autio et al., 2018; Mason and Brown, 2013; Pitelis, 2012; Spigel and Harrison, 2018).

Entrepreneurship is essentially a collective phenomenon that links the entrepreneur to local resources. The local dimension reflects the development of the entrepreneurial 
$\mathrm{MD}$

59,13

118

ecosystem (Scheidgen, 2021; Voelker, 2012). An entrepreneurial ecosystem is an opportunity for start-ups: is a space from which actors can draw resources (Autio et al., 2018; Scheidgen, 2021). Thus, entrepreneurial ecosystems need to help the youngest and weakest become more robust and competitive players in their reference markets (Pitelis, 2012). The entrepreneurial ecosystem approach has origins in both the regional development and the strategy literature. It finds itself at the confluence of the knowledge ecosystem and the business ecosystem, while integrating an innovation ecosystem logic (Dias Sant'Ana et al., 2020; Nambisan and Baron, 2013; Scaringella and Radziwon, 2018). A knowledge ecosystem is seen as contributing to the generation of knowledge thanks to actors' geographical proximity (Clarysse et al., 2014).

Business ecosystem analysis, on the other hand, goes beyond the traditional framework of industry and geographical boundaries, to include all the strategic relationships that a focal company establishes to create a community of heterogeneous allies (Adner, 2017; Teece, 2007). It can be broadly defined as a set of actors with whom a company interacts directly or indirectly to create and implement a value proposition. This business ecosystem ultimately comprises all relevant, multiple and diverse relationships of the firm. Within these relationships, some actors are located on the territory of the start-up and thus emerge from its entrepreneurial ecosystem. Our research question investigates the importance for start-ups of actors from their entrepreneurial ecosystem. We relate to factors inherent to the start-ups that may influence their degree of reliance on these actors. The graphical representation of different actors and their belonging to a firm's entrepreneurial ecosystem, its business ecosystem or both is presented in Figure 1.

A larger network facilitates access to the resources necessary for a start-up's development (Lechner and Dowling, 2003; Semrau and Werner, 2014). But the question of what drives start-ups to establish relationships beyond their local environment remains open (Kuratko et al., 2017). Innovative companies need significant resources and are particularly dependent on knowledge (Nylund and Cohen, 2017). One of the advantages associated with geographical clusters is that they provide small and young innovative companies with easier access to resources thanks to geographical proximity (Acs and Audretsch, 2005; Iacobucci and Perugini, 2021).

While an entrepreneurial ecosystem may include several clusters, entrepreneurship is inextricably linked to a region, the geographical environment where start-ups exploit opportunities or obtain resources (Thornton and Fkynn, 2005). Furthermore, territorial anchoring is particularly important for the development of high-tech SMEs, as it gives young innovative companies access to support mechanisms for business creation and development (Autio et al., 2018; Theodoraki et al., 2018). Geographical proximity facilitates interactions and is associated with facilitated knowledge transfer and innovation (Kolympiris and

Figure 1. Business and entrepreneurial ecosystems

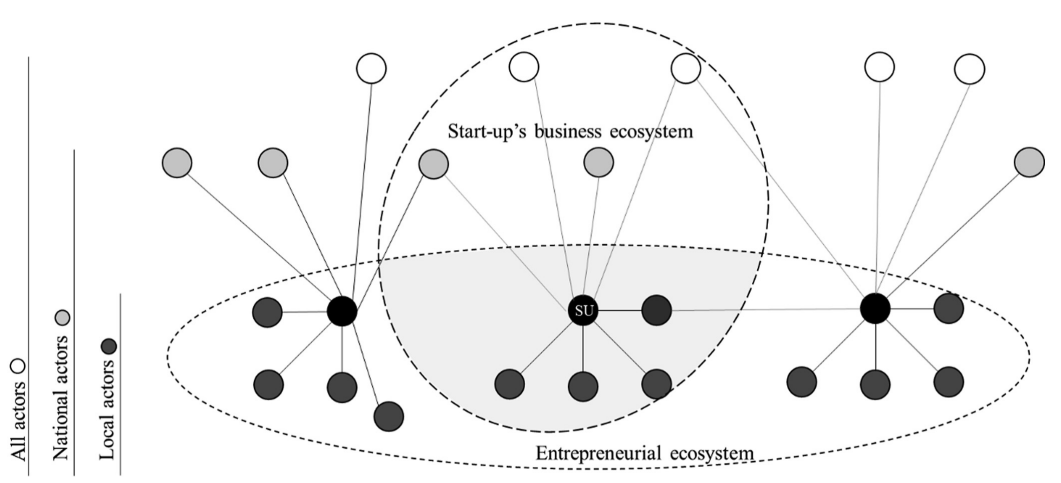


Kalaitzandonakes, 2013). Obtaining knowledge at a distance entails relatively higher costs (Acs and Audretsch, 2005) although increasing digitalization can reduce this cost (Nambisan, 2017). For example, venture capitalists tend to finance nearby start-ups. Increased distance makes it more difficult for them to identify a target and reduces their ability to provide assistance and exercise control (Sorenson and Stuart, 2001). Overall, entrepreneurial ecosystems are privileged places to promote the sharing of knowledge between geographically close start-ups (Autio et al., 2018). In this context, as Audretsch et al. (2021) point out, the actors' behaviors and their interactivity are important because they foster entrepreneurial activity and therefore drive the entrepreneurial ecosystem evolution.

Research on entrepreneurial ecosystems has studied areas across the globe. Recent examples include Australia (Haines, 2016), Brazil (Arruda et al., 2015), Canada (Spigel, 2017), Israel (Kon et al., 2014), France (Theodoraki et al., 2018) or USA (Mack and Mayer, 2016). However, the use of interview based, qualitative case studies remains frequent, which is insufficient to explain entrepreneurial ecosystems (Stam and Spigel, 2017). Thus, we base our investigation on the quantitative analysis of an overall start-up community in the Toulouse area in France.

\section{Characteristics of start-ups and reliance on their entrepreneurial ecosystem}

The definition of start-ups as young, small and innovative companies capable of rapid growth (Wickham, 2004) includes three important characteristics of entrepreneurial ventures.

The first dimension is the age of a start-up. Young firms are characterized by limited relational capacity, which will initially lead them to develop primarily local relationships, highlighting the importance of a functioning entrepreneurial ecosystem (Vedula and Kim, 2019). This capacity to develop and maintain relationships increases with the age of the firm (Lechner and Dowling, 2003): Increased relational capacity will result in more relationships, which will decrease the probability of only local relationships. In addition, a firm's age influences the type of network on which it relies (Littunen and Niittykangas, 2010) and its geographical scope (Kaufmann et al., 2003). Older start-ups are more advanced in their development cycle. They have more relational capacity and look for interactions that are less dependent on their immediate geographical environment (Presutti et al., 2013). Hence, when relational capacity increases, the relative importance of relationships from the start-up's entrepreneurial ecosystem should decrease. The proportion of relationships from the entrepreneurial ecosystem in the overall set of all business relationships therefore declines as the firm develops more relationships and grows older. This leads to our first two hypotheses:

H1. An increasing number of relationships will reduce a start-up's reliance on actors from its entrepreneurial ecosystem.

H2. The older a start-up is, the less it will rely on actors from its entrepreneurial ecosystem.

Second, the size of the start-up comes as a corollary to the age question (Wincent, 2005). Geographical proximity is more important for small and young companies operating in a technological environment (Jansson, 2008). Thus, small companies tend to be more locally anchored than large companies (Feld, 2012). Small firms favor local search processes for access to information, knowledge and nearby contacts (Kolympiris and Kalaitzandonakes, 2013) and benefit more from geographical proximity with others than large companies do (Acs and Audretsch, 2005; Autio et al., 2018). While the main concern of small businesses is to access the resources available to most actors in an entrepreneurial ecosystem, large companies have an interest in developing beyond the public benefits provided by an entrepreneurial ecosystem: They have an interest in developing a network that offers specific advantages (Lechner and Leyronas, 2012). Our third hypothesis is therefore: 
$\mathrm{MD}$

59,13

120

H3. The larger a start-up, the less it will rely on actors from its entrepreneurial ecosystem.

An implicit assumption of our first three hypotheses is that the local environment might ultimately not provide enough quality relationships. The more actors populate an entrepreneurial ecosystem, the less this general assumption becomes valid. However, if many actors possessing differing degrees of relational capacity populate an entrepreneurial ecosystem, then some firms might preempt others. In other words, some firms may capture an overproportional number of local relationships and attention. The question of access to new relationships thus becomes a probabilistic one. Our first hypotheses need to be understood in this sense. Given limited relational capacity, the more relationships a firm has, the older and the larger it is, the more likely it is to build relationships outside its entrepreneurial ecosystem. However, this does not fully account for the competitive situation for relational development.

In an entrepreneurial ecosystem, proximity between companies and institutions is expected to foster knowledge and innovation transfer between actors (Autio et al., 2018; Kolympiris and Kalaitzandonakes, 2013). In fact, the more a company is based on advanced technology, the more it looks to local investors with specific knowledge (Harrison et al., 2010). Entrepreneurial ecosystems can be expected to be specialized in certain domains, so that innovative companies can mobilize local expertise. Furthermore, the close relationships that provide the in-depth interactions necessary to generate innovation are mainly local (Lechner and Dowling, 2003). Informal relationships within a specialized environment, thematic events, large companies that may be former employers and/or potential clients or research laboratories that may provide interns, are all elements that promote innovation in an entrepreneurial ecosystem (Stam, 2015). Innovation is therefore facilitated by geographical proximity as well as by the type of interactions between actors, two important aspects of entrepreneurial ecosystems (Funk, 2014; Mattes, 2012).

While we could hypothesize that more innovative firms would rely on the local entrepreneurial ecosystem, this would ignore relational capacity. An additional element that drives relational capacity is the gravity of a firm within its local context: The more important an actor is within its entrepreneurial ecosystem, the easier it will be for this actor to develop new ties, since its attractiveness as a partner increases for others (Lechner and Leyronas, 2012). Firm size provides an indicator of its relational gravity and has been shown to have a moderating effect on the relationship between innovative behavior and performance (Ha-Brookshire, 2009). Innovative firms need relationships to sustain and extend their innovation capacity. The compensation hypothesis states that firms will seek outside relationships if they are unable to access local relationships with reasonable effort (Lechner and Leyronas, 2012). As such, we would expect older, and more established firms to derive relational benefits from size (see Figure 2).

Larger and more innovative firms should be able to rely more on their entrepreneurial ecosystem than other firms. They are more likely to obtain local financing, win local subsidies

Figure 2.

Research model

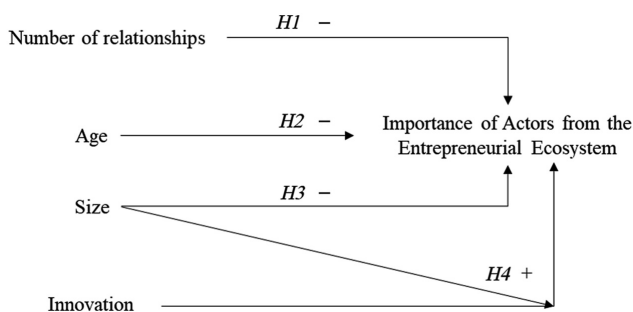


or research grants, develop local technology alliances, be staged at public events and so on, and this happens largely at the expense of smaller and younger counterparts. This suggests that these more powerful firms exploit best the entrepreneurial ecosystem and the locally available resources. While counterintuitive, this logic is a consequence of differing relational capacity putting younger and smaller innovative firms at a disadvantage. Hence, our last hypothesis:

H4. The reliance of more established and more innovative firms on the entrepreneurial ecosystem is positively moderated by firm size, that is, larger and innovative firms will rely more on their entrepreneurial ecosystem.

\section{Methodology}

Delimitation of the area of investigation

A community is defined as a proximal spatial area that is smaller than a state (Hopp and Stephan, 2012). In this sense, the Toulouse area in southwest France represents a particularly interesting community to study entrepreneurship and innovation dynamics. Toulouse is the capital of the second largest region in France, Occitanie. In 2014, it was one of the first cities to receive the "French Tech" certification, which aims to promote the emergence of French startups. In April 2019, the government selected its "ANITI" project as one of four Interdisciplinary Institutes for Artificial Intelligence in France.

A report assessing the attractiveness of large French metropolitan area recently ranked Toulouse in the second place, based on a selection of criteria covering: economic performance, tertiary real estate and business reception, connectivity, human capital, innovation and, finally, quality of life (Torossian et al., 2020). In particular, this report highlights Toulouse's top position in terms of economic indicators, demographic dynamism and connectivity. The high qualification of its working population (highest education level) is also put forth as a strong indicator of human capital. In addition, in 2020, French Tech Toulouse launched an index to track fundraising by Toulouse tech companies. In the third trimester of 2020, nine operations amounted to $€ 25.5 \mathrm{~m}$, which confirms the dynamism of these companies (Rioux, 2020). Altogether, the area offers fertile grounds for entrepreneurial ecosystem research.

\section{Analysis of hyperlinks and digital methods}

Ecosystem research, including entrepreneurial ecosystems research, presents particular challenges that might require scholars to go beyond traditional methods of empirical data collection (Adner, 2017; Brown and Mason, 2017; Wurth et al., 2021). Our research question involves a measure of the proportion of local relationships among the overall relationships of start-ups. Identifying all the formal and informal relationships that a company establishes throughout its existence would not be possible. However, "Digital Methods" offer an alternative solution (Meza and Park, 2016; Raisi et al., 2018; Rogers, 2013; Shore et al., 2018).

These methods are based on the observation that an actor's (individual or company) real connections to other actors are reflected in its Internet activities. Following this approach, we focused on the hypertext links found on start-ups' websites. The study of the different connections between actors can reveal large communities, representing "hypertext ecosystems". It can be done automatically, for example using crawler tools that identify and index all outgoing links on a blog or a website (Rogers, 2013) or manually (de Maeyer, 2013). A manual study is certainly tedious (it involves an individual examination of each page), but it is also more precise.

The actors mentioned on a start-up's website correspond to an extensive network that we consider to be representative of its business ecosystem (funders, suppliers, technological partners, customers, public institutions, etc.), as they comprise actors that the start-up 
$\mathrm{MD}$

59,13

considers to be so important as to mention them. Furthermore, by identifying the local actors among all the start-ups' connections, we can reconstruct the common entrepreneurial ecosystem that they all belong to. In addition, our manual census method makes it possible to eliminate purely functional and technical links.

As individual actors tend to create hyperlinks with their allies, analyzing them through digital methods has been shown to offer interesting potential for understanding interactions (Elgin, 2015). The start-up chooses which partners to include on its website. It is a deliberate and public choice to indicate with which other companies and institutions it works. In other words, the hyperlinks on a start-up site, although they are not necessarily exhaustive with regard to all its relationships, highlight the actors supporting its legitimacy.

\section{Data collection and sample selection}

The attractiveness of the Toulouse metropolitan area and, in particular, the assessment of its economic performance, connectivity, human capital and innovation (Torossian et al., 2020), make it an appropriate candidate for entrepreneurial ecosystems research.

The starting point for identifying the start-ups of the Toulouse region was a directory of more than 200 start-ups in the region (Le Startupper, 2016). This directory, compiled by specialists in the regional economy, provides a list of companies in the region with high growth potential. It is an annual publication that presents a selection of start-ups localized in the region. It is published by the group "La Tribune", which specializes in business and economic publications. Starting from this independent publication ensures objectivity in the selection of start-ups.

Our research focus is related to the type of geographical proximity inherent to entrepreneurial ecosystems (Mason and Brown, 2013). Thus, we only selected companies located in the same administrative department as Toulouse (Haute-Garonne, department number 31). These represented $86.4 \%$ of the companies listed in the directory. From the directory, we collected for each start-up: the number of employees, founding date, names of the managers and the list of actors who provided them with support. We then visited their individual websites in January 2016 to identify the other actors that they mentioned as partners.

From an empirical point of view, age is a key indicator for the inclusion of start-ups in a study. However, the accepted limit in research varies, with examples ranging from less than three years (Vapola, 2011), up to 15 years (Tegarden et al., 2000). Nevertheless, the 10-year age limit seems to be commonly accepted (Krishna and Subrahmanya, 2015). Therefore, our sample only includes companies founded within the last 10 years.

We identified 180 companies in the directory meeting these two criteria (location and age) and thus composing our initial sample. However, 17 had to be withdrawn because of missing relational data. Our final sample therefore includes 163 companies. Our method allowed us to identify connected actors for $91.7 \%$ of the initial sample. In order to conduct a consistent analysis and eliminate possible biases in the selection of surviving companies, we divided the sample in two groups based on age. The youngest are start-ups aged 1-4 years at the time of data collection (Group A: 111 companies). The oldest are start-ups between 5 and 10 years old at the time of data collection (Group B: 52 companies).

\section{Variables}

Dependent variable. The variable "Importance of Actors from the Entrepreneurial Ecosystem" (IAEE) captures the ratio representing the percentage of relationships with actors from the entrepreneurial ecosystem within the overall relationships of the start-up. To calculate this variable, we needed to measure geographical proximity. Spatial separation between actors is traditionally reported as a metric measure of physical distance (Balland, 2012). However, the 
evolution of communication means calls for a similar spatial area criterion between actors (Balland, 2012). We therefore chose the European Union (Eurostat) NUTS-2 classification and selected the region as the delimitation of the entrepreneurial ecosystem (Table 1). We coded all the identified actors as belonging to one of these areas, with 1 representing the most local ones.

Independent variables. These refer to Wickham's (2004) definition of start-ups as young, small and innovative companies capable of rapid growth. Specifically, the overall number of actors identified in the start-ups' relationships was used for number of relationships. In our analysis, age is measured as the number of years since the start-up was created and size as the number of employees. While these are often used objective criteria (Dobbs and Hamilton, 2007), innovation, our fourth independent variable, may be more delicate to measure (Adams et al., 2006). The young age of the start-ups in our sample implies difficulty in accessing their financial accounts and that some will be relying on shared R\&D efforts. What is more, their innovative character is not necessarily based on patenting.

Following other scholars, we relied on a coding approach of perceived innovation based on qualitative data (Kuratko et al., 2017; Täuscher and Laudien, 2018; Zott and Amit, 2007). Thus, two entrepreneurship researchers assessed start-ups separately based on information provided in the directory (Le Startupper, 2016) and on the start-ups' websites. Various criteria such as the value proposition contribution, degree of novelty, business model's development potential or development of a new technology were taken into consideration (Kuratko et al., 2017; Zott and Amit, 2007). The start-ups' degree of innovation was rated on a scale from 1 (low) to 6 (high) and recorded as the average grade given by the two raters (Tables 3 and 4). When a greater than one-point discrepancy in assessment arouse (15\% of cases), the researchers discussed the case to reach an agreement. In the end, the average of the rating given by the two experts provides a consistent assessment of the start-ups' degree of innovation (average difference: 0.16$)$ [1].

\section{Results}

Given the importance of understanding the context in the study of entrepreneurial ecosystems (Spigel, 2017; Voelker, 2012), we first present an overview of the distribution of the relationships identified. We then use regression analysis to test our hypotheses.

\section{Overview of relationships}

The method presented above enabled us to identify 1,633 relationships involving 638 different actors ( $22.51 \%$ as "support", $31.38 \%$ as "clients" and $46.12 \%$ as "partners"). Of these, 371 belong to the entrepreneurial ecosystem. For these 371 actors, the Blau index, which measures the degree of variety of actors according to categorical variables (Harrison and Klein, 2007), is 0.9877 . This indicates no concentration of relationships around a small number of actors. However, the top 19 actors (out of 371 or just over $5 \%$ ) are involved in $41.41 \%$ of the total relationships.

1.

2.

Toulouse and its department (Haute-Garonne, 31)

Rest of the Occitanie region

Entrepreneurial ecosystem

3. Institutions with local branches in Toulouse

4. Rest of France

5. Rest of Europe

6. Rest of the world

Table 1.

Delineation of the entrepreneurial ecosystem 
$\mathrm{MD}$

59,13

Not surprisingly, the majority of support actors are located in the administrative department. On the other hand, more than $50 \%$ of clients are located at the national level, while partners are distributed between the department and national levels. Finally, while half of the overall relationships identified are within the Toulouse entrepreneurial ecosystem, only very few are established at the international level (Table 2).

Start-ups characteristics and importance of the entrepreneurial ecosystem

The descriptive statistics of the sample are presented in Table 3 (Group A: 1-4 years old) and Table 4 (Group B: 5-10 years old). In terms of activities pursued by the start-ups in the sample, a variety of sectors are represented but digital (IoT, software) stands out with $46 \%$ of the start-ups in this field. While just under $50 \%$ of the actors belong to the Toulouse entrepreneurial ecosystem (Table 2), start-ups have $65 \%$ of their relationships with these actors, which highlights the importance of the entrepreneurial ecosystem for them. In addition, the use of the entrepreneurial ecosystem is higher for Group A ( 0.69 versus 0.56 ), and companies in Group B are assessed as more innovative (4.09 versus 3.06).

Correlation analysis indicates that, regardless of the group, the more relationships a firm has, the less it uses its entrepreneurial ecosystem. In line with our first two hypotheses, the importance of relationships with actors from the entrepreneurial ecosystem is negatively related to its age and size, although only statistically significant for Group A.

\begin{tabular}{|c|c|c|c|c|c|c|c|}
\hline & \multicolumn{3}{|c|}{ Entrepreneurial ecosvstem } & \multicolumn{3}{|c|}{ Outside EE } & \\
\hline & $\begin{array}{c}\text { Department } 31 \\
(\%) \\
1\end{array}$ & $\begin{array}{c}\text { Occitanie } \\
\text { region }(\%) \\
2\end{array}$ & $\begin{array}{c}\text { Local agency } \\
(\%) \\
3\end{array}$ & $\begin{array}{c}\text { France } \\
(\%) \\
4\end{array}$ & $\begin{array}{c}\text { Europe } \\
(\%) \\
5\end{array}$ & $\begin{array}{c}\text { World } \\
(\%) \\
6\end{array}$ & \\
\hline Support & 69.75 & 1.09 & 12.53 & 13.62 & 2.18 & 0.82 & \\
\hline Customer & 21.25 & 5.07 & 0.97 & 53.80 & 10.72 & 8.19 & \\
\hline Partner & 36.25 & 5.18 & 4.52 & 40.64 & 6.24 & 7.17 & 1 \\
\hline Total & 39.07 & 4.23 & 5.21 & 38.70 & 6.74 & 6.06 & 1 \\
\hline Cumulative & 39.07 & 43.29 & 48.50 & 87.20 & 93.94 & 100.00 & \\
\hline
\end{tabular}

Table 2.

Distribution of actors by geographical area

\begin{tabular}{lrrrrrrr}
\hline$n=111$ & $\bar{x}$ & $\sigma$ & 1. & 2. & 3. & 4. & 5. \\
\hline 1. Number of relationships & 7.68 & 9.25 & 1 & & & \\
2. Age & 2.25 & 1.07 & 0.18 & 1 & & \\
3. Size & 3.60 & 4.41 & $0.20^{*}$ & $0.35^{* * *}$ & 1 & & \\
4. Innovation & 3.06 & 1.31 & 0.10 & $0.35^{* * *}$ & $0.47^{* * *}$ & 1 & \\
5. IEEA & 0.69 & 0.30 & $-0.39^{* * * *}$ & $-0.27^{* *}$ & $-0.25^{* *}$ & -0.09 & 1 \\
Note(s): ${ }^{* * *}$, and ${ }^{* * * *}$ denote significance at the 10,5 and $1 \%$ levels, respectively & & \\
\hline
\end{tabular}

\section{Table 3.}

Description and correlations of variables - Group A (firm age: $1-4$ years)

\begin{tabular}{lrrrrrrr}
\hline$n=52$ & $\bar{x}$ & $\sigma$ & 1. & 2. & 3. & 4. & 5. \\
\hline 1. Number of relationships & 13.33 & 12.83 & 1 & & & & \\
2. Age & 6.88 & 1.71 & -0.22 & 1 & & & \\
3. Size & 14.35 & 21.17 & -0.06 & -0.01 & 1 & & \\
4. Innovation & 4.09 & 1.26 & -0.17 & 0.02 & 0.26 & 1 & \\
5. IEEA & 0.56 & 0.31 & $-0.39^{* * *}$ & -0.14 & 0.05 & 0.14 & 1 \\
Note(s): ${ }^{* * *}$ and ${ }^{* * * *}$ denote significance at the 10,5 and $1 \%$ levels, respectively & & & \\
\hline
\end{tabular}


Next, in order to test our hypotheses, we use regression analysis (Tables 5 and 6): Model 1 presents the first explanatory variable, namely number of relationships, Model 2 integrates the three explanatory variables and innovation, Model 3 introduces the interaction term corresponding to the test of hypothesis 4 . We use the traditional procedure of interaction measurement (Cohen et al., 2003; Frazier et al., 2004): after centering our independent variables in order to avoid multicollinearity problems, we calculate the product between these variables.

Results for the youngest group of start-ups show that the more relationships the start-up has, the less it relies on its entrepreneurial ecosystem (Models 1 to 3). Age also appears as a variable that reduces the use of the entrepreneurial ecosystem (Models 2 and 3). These results are in line with our first two hypotheses. However, hypotheses 3 and 4 are not confirmed for this group.

For older start-ups (Table 6), we see the same pattern. The results sustain hypotheses 1 and 2. Hypothesis 3 is not confirmed. With regard to innovation, we detect a positive relationship (Model 3) between the entrepreneurial ecosystem when we introduce the "Size $\times$ Innovation" interaction terms. So, hypothesis 4 cannot be rejected for this group, suggesting that an increase in innovation favors the reliance on local actors for the largest start-ups. Figure 3 presents this interaction effect.

We now discuss the implications of these results.

\begin{tabular}{|c|c|c|c|}
\hline$n=111$ & 1. & 2. & 3. \\
\hline Constant & $0.79^{\text {**** }}$ & $0.69^{* * *}$ & $0.68^{* * * *}$ \\
\hline Number of relationships & $-0.01^{* * *}$ & $-0.01^{* *}$ & $-0.01^{* *}$ \\
\hline Age & & $-0.05^{*}$ & $-0.05^{+}$ \\
\hline Size & & -0.01 & -0.01 \\
\hline Innovation & & 0.02 & 0.02 \\
\hline Size $\times$ innovation & & & 0.00 \\
\hline Adjusted $R^{2}$ & 0.14 & 0.18 & 0.17 \\
\hline$F$ & 19.12 & 7.07 & 5.66 \\
\hline
\end{tabular}

$N \quad 111 \quad 111 \quad 111$

Note(s): ${ }^{+} p<0.1 ;{ }^{*} p<0.05 ;{ }^{* * *} p<0.01 ;{ }^{* * * *} p<0.001$

$\mathrm{DV}=$ IAEE (Importance of Actors from the Entrepreneurial Ecosystem)
Table 5.

Regression analysis (standardized coefficients)-Group A (firm age: $1-4$ years)

\begin{tabular}{lccc}
\hline$n=52$ & 1. & 2. & 3. \\
\hline Constant & $0.69^{* * * *}$ & $0.56^{* * *}$ & $0.52^{* * * *}$ \\
Number of relationships & $-0.01^{* *}$ & $-0.01^{* *}$ & $-0.01^{* *}$ \\
Age & & $-0.04^{*}$ & $-0.05^{*}$ \\
Size & & 0.00 & $-0.01^{*}$ \\
Innovation & & 0.02 & $0.06^{+}$ \\
Size $\times$innovation & 0.13 & 0.14 & $0.01^{* *}$ \\
Adjusted $R^{2}$ & 8.70 & 3.07 & 0.23 \\
$F$ & 5.02 \\
Sign. $F$ & 52 & 52 & 52 \\
$N$ & & &
\end{tabular}

Table 6. Regression analysis (standardized coefficients) - Group B (firm age: $5-10$ years)
Start-ups in
entrepreneurial ecosystems

Note(s): ${ }^{+} p<0.1 ;{ }^{*} p<0.05 ;{ }^{* *} p<0.01 ;{ }^{* * * *} p<0.001$

$\mathrm{DV}=I A E E$ (Importance of Actors from the Entrepreneurial Ecosystem) 
$\mathrm{MD}$

59,13

126

\section{Discussion and opportunities for future research}

The extent to which entrepreneurial ecosystems fulfill their function to foster entrepreneurial firms and provide access to resources is at the heart of dedicated research (Audretsch et al., 2021). Our research contributes to research on entrepreneurial ecosystems by focusing on the start-ups' relationships in and outside their entrepreneurial ecosystem. The identification of interactions between actors in an ecosystem is considered a major challenge for entrepreneurial ecosystems research, particularly in order to go beyond the mere use of metaphors (Wurth et al., 2021). Network density is considered a necessary condition of functioning entrepreneurial ecosystems and lack of it denotes a partial system failure (Stam, 2015; Stam and Van de Ven, 2021). Our research extends the current literature by providing insights about the importance for start-ups of relationships from the entrepreneurial ecosystem compared to their overall business relationships (Autio et al., 2018; Iacobucci and Perugini, 2021; Jacobides et al., 2018; Scaringella and Radziwon, 2018). Two basic assumptions guide it: First, different actors have differing access to relationships in their local entrepreneurial ecosystem because of differing relational capacity (Lechner and Leyronas, 2012); and second, entrepreneurial firms need sufficient access to complementary resources (Aldrich and Fiol, 1994). This research is therefore part of a contingent approach of resource access in an entrepreneurial ecosystem (Scheidgen, 2021).

This research makes contributions on three levels. First, from a theoretical point of view, it provides a better understanding of the characteristics driving the interactions of startups with their entrepreneurial ecosystems by adopting a relational capacity approach (Audretsch et al., 2021; Dyer and Singh, 1998; Iacobucci and Perugini, 2021; Lechner and Dowling, 2003; Motoyama and Knowlton, 2017; Roundy et al., 2017; Scheidgen, 2021). The selected angle of analysis is interested in the actual relational behaviors of actors and is thus takes a micro perspective aimed at identifying underlying causal mechanisms (Audretsch et al., 2021; Wurth et al., 2021). Second, from a practical point of view, our research should be of interest to public authorities seeking to promote the link between local resources and the development of innovative start-ups in their regions. Indeed, research on entrepreneurial ecosystems, and the role of public policy, is increasingly addressing the issue of enhancing local performance through entrepreneurial activity (Colombo et al., 2019). Finally, from a methodological point of view, our identification of hypertext ecosystems based on digital methods (de Maeyer, 2013; Meza and Park, 2016; Raisi et al., 2018; Rogers, 2013; Shore et al., 2018) represents an innovative approach for uncovering firms' ecosystems (Adner, 2017).

Figure 3.

Moderating effect of size on "Innovation Importance of Actors from the Entrepreneurial Ecosystem" relationship (Group Bfirm age: 5-10 years)

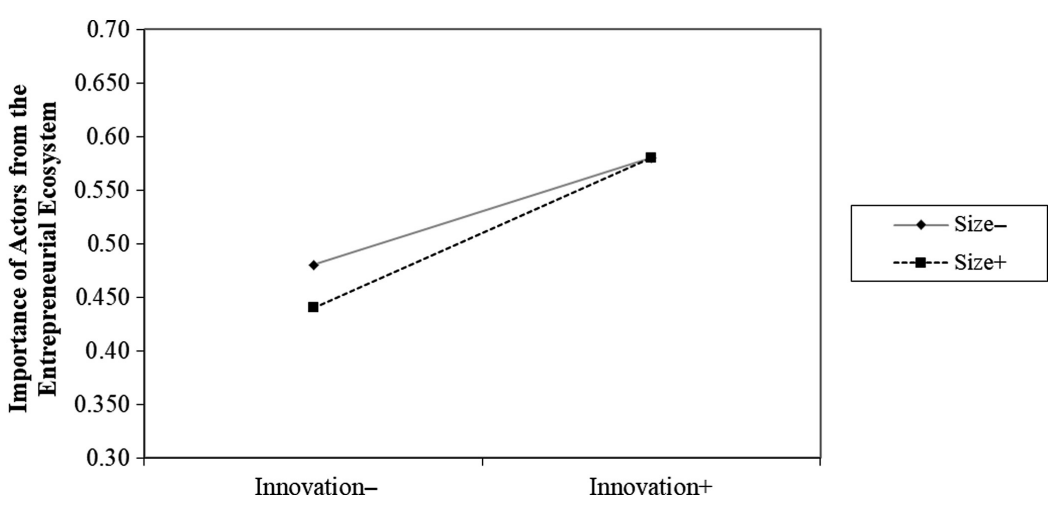


Theoretical and practical implications: the role of relational capacity in entrepreneurial ecosystems

Overall, our results shed light on the importance of local relationships for start-ups by illustrating quantitatively the usefulness of the entrepreneurial ecosystem concept (Acs et al., 2017; Autio et al., 2018; Isenberg, 2011; Mason and Brown, 2013; Spigel, 2017; Voelker, 2012; Wurth et al., 2021). They also show the importance of analyzing local structures to better understand how entrepreneurship and innovation interact (Autio et al., 2014; Colombo et al., 2019; Iacobucci and Perugini, 2021; Lechner and Leyronas, 2012). The relationship we identify between a company's age and its decreasing dependence on its entrepreneurial ecosystem is consistent with the results of Sorenson and Stuart (2001) and Presutti et al. (2013) but contradicts those of Harrison et al. (2010). These results concur with those suggesting that strong local integration is a first step for young start-ups to establish their legitimacy and competitiveness (Lechner and Leyronas, 2012; Scheidgen, 2021; Woolley and MacGregor, 2021).

Moreover, and unlike Harrison et al. (2010) or Funk (2014), we do not identify innovation per se as a significant influence on the geographical expansion of start-ups' relationships. Interestingly however, we find that the relationship between innovation and the use of the entrepreneurial ecosystem is influenced by the interaction between innovation and size. Specifically, our results (Table 6) suggest that the larger a company is, the more its innovation will lead it to turn to local partners compared to smaller companies. This result may seem surprising, as our review of the literature led us to suggest that a large size would reduce firms' reliance on their entrepreneurial ecosystem. Our interpretation relates to active differentiation versus gravity (Lechner and Leyronas, 2012). It also appears to indicate that innovative firms draw from local resources as much as they can.

While this result is in line with what creates more competitive firms in clusters, in entrepreneurial ecosystems, it rather indicates partial system failure (Stam, 2015). On the one hand, small and innovative start-ups might find fewer actors working in their field in the entrepreneurial ecosystem or willing to engage with them. The dominance of larger, older and more innovative firms might create some form of system ineffectiveness. One of the objectives of entrepreneurial ecosystems is to nurture the embryonic and young firms. However, limited relational capacity might limit their access to the system's resources. These firms - the typical subject of entrepreneurial ecosystem policy - might have an interest to actively network outside the region in order to differentiate themselves from their peers.

On the other hand, larger and innovative firms develop some form of gravity, which allows them to attract larger numbers of local firms (note that we controlled for the total number of relationships). For example, in Toulouse, one cluster called "IoT Valley" was originally led by the connectivity provider Sigfox with the objective of gathering start-ups seeking to incorporate its technology in their development. Hence, we interpret this result as a possible indication of cluster effects within the overall entrepreneurial ecosystem, where large innovative firms seek to become centers of gravity and preferred partners for other actors.

We believe that this apparently paradoxical result of the lower importance of local actors for smaller innovative start-ups could reflect additional conditions: First, the choice of highly specialized niche strategies that reduce the likelihood of finding specific local partners and would encourage companies to maintain relationships with more distant actors; and second, a lack of local anchoring and limited relational capacity of smaller firms that reduce their ability to interact with specific partners locally compared to larger more legitimate actors (Lechner and Leyronas, 2012; Woolley and MacGregor, 2021).

An alternative explanation is proposed by Kuratko et al. (2017) who believe that the importance of the novelty proposed by a start-up pushes it out of its entrepreneurial ecosystem in order to gain legitimacy. The small size would then lower the innovation threshold for the start-up to reach out of its entrepreneurial ecosystem and rely more on 
$\mathrm{MD}$

59,13

128

distant partners. If we critically interpret the implications of our results, then entrepreneurial ecosystems partially fail to provide sufficient resources to start-ups as gravity effects favor more powerful firms. These start-ups need to reach out of the entrepreneurial ecosystem, which is also not obvious given their limited relational capacity. What might beneficial for the competitiveness of clusters (Lechner and Leyronas, 2012) might not have the same beneficial effects for the functioning of entrepreneurial ecosystems.

From a practical point of view, for public decision makers, strengthening the link between smaller (less visible) innovative start-ups and their environment could provide an interesting lever for improvement. In fact, our results suggest that start-ups' age (more than size) is an important criterion for targeting such support. Dedicated activities targeted exclusively at younger firms could therefore be implemented. For instance, technology pitches for start-ups that are not yet operational could be organized. The objective of such events would be to give young start-ups increased visibility and enable them to expand the relationships in their entrepreneurial ecosystem in order to rely on them for their early stage development. Provision of sufficient seed funding compared to later stage investment is another option. For instance, as described by Lerner (2020), in Israel, public matching funds may be structured so as to favor start-ups at the seed stage, by decreasing the ratio of the matching fund investments as startups progress through development stages. In any case, if gravity effects are present in entrepreneurial ecosystems, then policy measures should seek to nurture the youngest (and weakest) and give them privileged access to the ecosystem's resources. This implication appears almost paradoxical for entrepreneurial ecosystems; however, heightened awareness to issues of network gravity and the inner dynamics is crucial to avoid system failure (Stam, 2015). Our research suggests that less innovative firms tend to search relationships outside the region. Or, put in other words: Those firms that would need more help from their entrepreneurial ecosystem need to reach outside the region for crucial resources.

Entrepreneurial ecosystems provide resources for start-ups and enable innovative companies to emerge and grow (Wurth et al., 2021). However, the maturity of entrepreneurial ecosystems and their degree of specialization vary, as do the needs of start-ups (Scheidgen, 2021). By adopting a contingent approach, our results imply a more specific consideration of these start-ups' needs and can help public authorities in the creation or orientation of structures present in the entrepreneurial ecosystem. Following the same logic, a start-up can reflect on its choice of location in a given entrepreneurial ecosystem because not all provide the same resources. Specifically, for our research area (Toulouse), but also for other metropolitan areas with similar characteristics, we suggest that policy makers take into account the limited use of local resources by young innovative companies. Accessing these resources requires a dedicated activity within the company and this may be difficult for companies with low visibility. The launch of common working spaces gathering important actors from the entrepreneurial ecosystem goes in this direction. However, the selection of firms into these co-working spaces needs to assure a mix of well-connected and less connected firms in order to facilitate access to a variety of potential partners. The mutualization and sharing of resources made possible by such places is of particular importance for young startups. From this point of view, it also makes sense to group support activities dedicated to firms at different development stages under one roof. Physical spaces that host preincubation, incubation and acceleration services would allow for interaction of more heterogeneous firms. In addition, we believe that the implementation of targeted activities by public authorities can be useful. For example, partnerships with research institutes or more generally universities, which have graduated the creators of these companies, could allow early identification of these young and innovative startups. We can also suggest setting up funds dedicated to startups with specific and restrictive eligibility criteria (very young and small size). Communication operations by public authorities targeted specifically at these companies should also be carefully designed. 
The distribution presented in Table 2 shows that, in addition to a strong representation of local relationships, many relationships with clients and partners are found at the national level but not at the international level. From a relational capacity perspective this makes sense, as firms simply extend their search process from local relationships to the next available level. However, focusing some analysis on the "born global" start-ups would perhaps provide a better understanding of the internationalization process of young startups. This observation could be particularly interesting for the design, implementation or evolution of policies to support business creation, with greater emphasis to be put on helping start-ups accessing international markets by overcoming limited individual relational capacity through collective public action. As far as public authorities are concerned, a series of measures can improve the international connections of start-ups in a given region. These include developing internationalization support structures, facilitating access to international trade fairs, providing access to internationalization advisors or connecting with foreign partners in relation to the type of innovation. The provision of international resources within the various types of incubators could also be interesting. The accelerated development of videoconferencing, linked to the COVID 19 health crisis, also provides the opportunity to hold working meetings with foreign partners at a lower cost.

Research has been silent on the relative weight of different firms in entrepreneurial ecosystems (Stam, 2015) and therefore on the issue of "who benefits most from an entrepreneurial ecosystem” (Autio et al., 2018; Colombo et al., 2019). Our results suggest that companies that would be expected to need least support, that is the most developed ones, are actually the ones benefiting most from local entrepreneurial ecosystems. Our theoretical contribution is to uncover the link that a start-up will have with its local environment, particularly in relation to its stage of development (Mack and Mayer, 2016). In the same vein as cluster research initially assumed generalized benefits for its members (Tallman et al., 2004), entrepreneurial ecosystems research seems to carry over the same implicit assumption. While gravity effects might have positive effects for clusters' competitiveness, it might lead to partial systems failure as it puts the (young) start-ups at a disadvantage. The implication of this insight is more critical for smaller and emerging entrepreneurial ecosystems where limited resources might be overproportionally captured by the large and more innovative firms, leaving little space for development of new firms. These conditions might influence the local choices of entrepreneurs and thus also the development of the ecosystem (Kolympiris et al., 2015). We believe that our research will be useful for the strategic considerations of start-up leaders and public authorities in choosing on which actors to focus their attention and initiatives (Alvedalen and Boschma, 2017). This reflection implies taking into account the evolution of entrepreneurial ecosystems. These change over time and the nature of the resources they may be able to provide also evolves (Audretsch et al., 2021; Gueguen, 2020).

\section{Methodological contribution: digital network construction}

The reconstruction of an entrepreneurial ecosystem from a large set of start-ups' relationships also represents a methodological contribution. We used Digital Methods to uncover hypertext ecosystems in the specific context of entrepreneurial ecosystems. Digital Methods correspond to a recent trend in human sciences (Meza and Park, 2016; Raisi et al., 2018; Rogers, 2013; Shore et al., 2018) and are widely used in sociology, political science, information science and geography (de Maeyer, 2013): they offer a promising avenue to analyze widespread relationships and their overall composition. The analysis of relationships through hypertext links is a way to understand the quest for legitimacy of the start-up (Kuratko et al., 2017) as well as its search for resources (Harrison et al., 2010). The construction of a start-up's digital network allows for a better understanding of its strategy and its reliance on local actors. 
$\mathrm{MD}$

59,13

This method has some advantages over traditional network analysis methods such as snowball interviews or populations surveys (Borgatti et al., 2018). It is a parsimonious method and based on publicly available data from the firms. Still it allows for control techniques by checking network symmetry in the case of smaller settings and full population data.

Hyperlinks on a website involve real social content that deserves to be analyzed (de Bakker and Hellsten, 2013; Hsu and Park, 2011; Raisi et al., 2018). As they represent a sign of association, none of them is there by chance (de Maeyer, 2013). By analyzing these relationships, a researcher can thus capture an important social construct from the relationships between members of a group with a common interest (Hsu and Park, 2011). However, while adding an actor via a hyperlink on a website may be a sign of trust and/or agreement with the partner, it can also be part of a communication strategy (Elgin, 2015). In addition, the intention of a hyperlink placed on a website is not always clear (de Maeyer, 2013): It may be an agreement, an opposition or a criticism (especially in the case of blogs). However, misinterpretation can be avoided by retaining only those websites and actors identified as partners or customers and identifying them manually rather than automatically. In order to understand whether this type of issue exists, research could confront the results of surveys with digitally constructed methods.

\section{Limitations and future research}

One limitation of this work is the fact that all locally based actors were considered as part of the entrepreneurial ecosystem. Following Isenberg's (2011) broad proposition in terms of the type of actors composing the entrepreneurial ecosystem, we considered all relationships highlighted by start-ups as effective, while some may indeed be more important than others. The second limitation is based on a possible partial identification of actors connected to startups using primary and secondary data and on our use of digital methods (Rogers, 2013). We are aware that this method has limitations such as partial survey, or reduced degree of interaction for example, but it also provides rich data and limits nonresponse biases, thereby enabling us to assess the positioning of start-ups' relationships with respect to their environment. Still, we recognize that taking into account the total number of Internet links as a measure of relational capital may lead to biases in the results obtained. In addition, the limited size of our sample and the cross-sectional nature of the data call for future research to investigate longitudinal evolutions of the composition of start-ups' relationships. Furthermore, particularities of the Toulouse entrepreneurial ecosystem might limit generalizability of our results. However, we share this limitation with other network studies based on regional networks.

This research could therefore be extended in several directions. First, replication studies in other ecosystems would be desirable. In particular, the methodology could be replicated to identify the nature of different entrepreneurial ecosystems in other regions and make comparisons. For example, within our work the specificity of Toulouse regarding aerospace is apparent, with Airbus, Aerospace Valley, or ESA as prominent actors. In addition, while our research treats all partners as equal, research aimed at contrasting the relationships in terms of the size of the partner could also represent an interesting direction. Finally, the use of local actors could also be influenced by criteria other than size, age or innovation. For example, at another level of analysis, it may be useful to study the social capital of start-up founders (Witt, 2004).

\section{Conclusion}

In this study, we adopted a relational capacity approach to understand the networking of start-ups inside and outside their entrepreneurial ecosystem. This approach predicts that limits in relational capacity will drive the networking behavior of start-ups. Highly limited 
relational capacity will initially favor the search for local relationships over distant ones. We then highlighted that older start-ups with more relationships rely less on their entrepreneurial ecosystem, while larger and more innovative start-ups tend to rely more on their entrepreneurial ecosystem, with this effect increasing with firm size. This was made possible by our use of a comprehensive digital data collection enabling us to reconstruct startup networks through hyperlinks present on their websites. We believe this method offers interesting research opportunities for scholars interested in the role of entrepreneurial ecosystems in the development of start-ups.

\section{Note}

1. For example, innovation was considered low (1) for a company distributing online ethically oriented Asian items (clothing and crafts) and high (6) for a company developing nanosensors to secure objects (tracking, anti-counterfeiting) in the context of the Internet of Things, strongly supported by research specialists and winner of various prizes related to innovation.

\section{References}

Acs, Z. and Audretsch, D. (2005), "Innovation and technological change", in Acs, Z. and Audretsch, D. (Eds), Handbook of Entrepreneurship Research, Springer Science, New York, pp. 55-80.

Acs, Z., Stam, E., Audretsch, D. and O'Connor, A. (2017), "The lineages of the entrepreneurial ecosystem approach”, Small Business Economics, Vol. 49 No. 1, pp. 1-10.

Adams, R., Bessant, J. and Phelps, R. (2006), "Innovation management measurement: a review", International Journal of Management Reviews, Vol. 8 No. 1, pp. 21-47.

Adner, R. (2017), "Ecosystem as a structure”, Journal of Management, Vol. 43 No. 1, pp. 39-58.

Aldrich, H.E. and Fiol, C.M. (1994), "Fools rush in? The institutional context of industry creation", Academy of Management Review, Vol. 19 No. 4, pp. 645-670.

Alvedalen, J. and Boschma, R. (2017), "A critical review of entrepreneurial ecosystems research: towards a future research agenda", European Planning Studies, Vol. 25 No. 6, pp. 887-903.

Arruda, C., Nogueira, V.S., Cozzi, A. and Costa, V. (2015), "The Brazilian entrepreneurial ecosystem of startups: an analysis of entrepreneurship determinants in Brazil and the perceptions around the Brazilian regulatory framework", in Lèbre La Rovere, R., de Magalhães Ozório, L. and de Jesus Melo, L. (Eds), Entrepreneurship in BRICS, Springer, Cham, pp. 9-26.

Audretsch, D. (2015), Everything in Its Place, Oxford University Press, New York.

Audretsch, D., Mason, C., Miles, M.P. and O'Connor, A. (2021), "Time and the dynamics of entrepreneurial ecosystems”, Entrepreneurship and Regional Development, Vol. 33 Nos 1-2, pp. 1-14.

Autio, E., Kenney, M., Mustar, P., Siegel, D. and Wright, M. (2014), "Entrepreneurial innovation: the importance of context", Research Policy, Vol. 43 No. 7, pp. 1097-1108.

Autio, E., Nambisan, S., Thomas, L.D.W. and Wright, M. (2018), "Digital affordances, spatial affordances, and the genesis of entrepreneurial ecosystems", Strategic Entrepreneurship Journal, Vol. 12 No. 1, pp. 72-95.

Balland, P.-A. (2012), "Proximity and the evolution of collaboration networks: evidence from research and development projects within the Global Navigation Satellite System (GNSS) industry", Regional Studies, Vol. 46 No. 6, pp. 741-756.

Borgatti, S., Everett, M. and Johnson, J. (2018), Analyzing Social Networks, 2nd ed., Sage, London.

Brown, R. and Mason, C. (2017), "Looking inside the spiky bits: a critical review and conceptualisation of entrepreneurial ecosystems”, Small Business Economics, Vol. 49 No. 1, pp. 11-30.

Canovas-Saiz, L., March-Chordà, I. and Yagüe-Perales, R.M. (2021), "A quantitative-based model to assess seed accelerators' performance", Entrepreneurship and Regional Development, Vol. 33 Nos 3-4, pp. 332-352. 
$\mathrm{MD}$

59,13

Clarysse, B., Wright, M., Bruneel, J. and Mahajan, A. (2014), "Creating value in ecosystems: crossing the chasm between knowledge and business ecosystems", Research Policy, Vol. 43 No. 7, pp. 1164-1176.

Cohen, B. (2006), "Sustainable valley entrepreneurial ecosystems", Business Strategy and the Environment, Vol. 15 No. 1, pp. 1-14.

Cohen, J., Cohen, P., West, S. and Aiken, L. (2003), Applied Multiple Regression/Correlation Analysis for the Behavioral Sciences, 3rd ed., Lawrence Erlbaum Associates, Mahwah.

Colombo, M.G., Dagnino, G.B., Lehmann, E.E. and Salmador, M. (2019), "The governance of entrepreneurial ecosystems", Small Business Economics, Vol. 52 No. 2, pp. 419-428.

de Bakker, F.G.A. and Hellsten, I. (2013), "Capturing online presence: hyperlinks and semantic networks in activist group websites on corporate social responsibility", Journal of Business Ethics, Vol. 118 No. 4, pp. 807-823.

de Maeyer, J. (2013), “Towards a hyperlinked society: a critical review of link studies”, New Media and Society, Vol. 15 No. 5, pp. 737-751.

Dias Sant'Ana, T., de Souza Bermejo, P.H., Moreira, M.F. and Vilas Boas de Souza, W. (2020), "The structure of an innovation ecosystem: foundations for future research", Management Decision, Vol. 58 No. 12, pp. 2725-2742.

Dobbs, M. and Hamilton, R.T. (2007), "Small business growth: recent evidence and new directions", International Journal of Entrepreneurial Behavior and Research, Vol. 13 No. 5, pp. 296-322.

Dyer, J.H. and Singh, H. (1998), "The relational view: cooperative strategy and sources of interorganizational competitive advantage", Academy of Management Review, Vol. 23 No. 4, pp. 660-679.

Elgin, D.J. (2015), "Utilizing hyperlink network analysis to examine climate change supporters and opponents", Review of Policy Research, Vol. 32 No. 2, pp. 226-245.

Feld, B. (2012), Startup Communities. Building an Entrepreneurial Ecosystem in Your City, John Wiley \& Sons, Hoboken, NJ.

Frazier, P.A., Tix, A.P. and Barron, K.E. (2004), "Testing moderator and mediator effects in counseling psychology research", Journal of Counseling Psychology, Vol. 51 No. 1, pp. 115-134.

Funk, R.J. (2014), "Making the most of where you are: geography, networks, and innovation in organizations", Academy of Management Journal, Vol. 57 No. 1, pp. 193-222.

Gueguen, G. (2020), "Les missions des associations constitutives des écosystèmes entrepreneuriaux", Revue Internationale PME, Vol. 33 No. 2, pp. 17-47.

Ha-Brookshire, J.E. (2009), "Does the firm size matter on firm entrepreneurship and performance? US apparel import intermediary case", Journal of Small Business and Enterprise Development, Vol. 16 No. 1, pp. 132-146.

Haines, T. (2016), "Developing a startup and innovation ecosystem in regional Australia", Technology Innovation Management Review, Vol. 6 No. 6, pp. 24-32.

Harrison, R. and Klein, K.J. (2007), "What's the difference? Diversity constructs as separation, variety, or disparity in organizations", Academy of Management Review, Vol. 32 No. 4, pp. 1199-12228.

Harrison, R., Mason, C. and Robson, P. (2010), "Determinants of long-distance investing by business angels in the UK", Entrepreneurship and Regional Development, Vol. 22 No. 2, pp. 113-137.

Hopp, C. and Stephan, U. (2012), "The influence of socio-cultural environments on the performance of nascent entrepreneurs: community culture, motivation, self-efficacy and start-up success", Entrepreneurship and Regional Development, Vol. 24 Nos 9-10, pp. 917-945.

Hsu, C.-1. and Park, H.W. (2011), "Sociology of hyperlink networks of Web 1.0, Web 2.0, and Twitter: a case study of South Korea”, Social Science Computer Review, Vol. 29 No. 3, pp. 354-368. 
Iacobucci, D. and Perugini, F. (2021), "Entrepreneurial ecosystems and economic resilience at local level”, Entrepreneurship and Regional Development, pp. 1-28. doi: 10.1080/08985626.2021. 1888318.

Isenberg, D. (2011), "Keynote address: how to froment an entrepreneurial revolution”, Paper Presented at the 10th, International Entrepreneurship Forum, Bahrain.

Jacobides, M.G., Cennamo, C. and Gawer, A. (2018), "Towards a theory of ecosystems", Strategic Management Journal, Vol. 39 No. 8, pp. 2255-2276.

Jansson, J. (2008), "Inside the internet industry: the importance of proximity in accessing knowledge in the agglomeration of internet firms in Stockholm”, European Planning Studies, Vol. 16 No. 2, pp. 211-228.

Kansheba, J.M.P. and Wald, A.E. (2020), "Entrepreneurial ecosystems: a systematic literature review and research agenda", Journal of Small Business and Enterprise Development, Vol. 27 No. 6, pp. 943-964.

Kaufmann, D., Schwartz, D., Frenkel, A. and Shefer, D. (2003), "The role of location and regional networks for biotechnology firms in Israel", European Planning Studies, Vol. 11 No. 7, pp. 823-840.

Kolympiris, C. and Kalaitzandonakes, N. (2013), "Geographic scope of proximity effects among small life sciences firms”, Small Business Economics, Vol. 40 No. 4, pp. 1059-1086.

Kolympiris, C., Kalaitzandonakes, N. and Miller, D. (2015), "Location choice of academic entrepreneurs: evidence from the US biotechnology industry", Journal of Business Venturing, Vol. 30 No. 2, pp. 227-254.

Kon, F., Cukier, D., Melo, C., Hazzan, O. and Yuklea, H. (2014), “A panorama of the Israeli software startup ecosystem”, 1 March. doi: 10.2139/ssrn.2441157.

Krishna, H.S. and Subrahmanya, M.H.B. (2015), “Transnational entrepreneurship and Indian high-tech start-up survival: an empirical investigation", South Asian Journal of Management, Vol. 22 No. 2, pp. 81-98.

Kuratko, D., Fisher, G., Bloodgood, J. and Hornsby, J. (2017), “The paradox of new venture legitimation within an entrepreneurial ecosystem", Small Business Economics, Vol. 49 No. 1, pp. 119-140.

Le Startupper (2016), L'écosystème des startups de Toulouse et de sa région, La Tribune, Toulouse.

Lechner, C. (2017), "The competitiveness of firms from a relational perspective", available at: https:// itunes.apple.com/it/book/competitiveness-entrepreneurial-firms-from-relational/id1282928707? $1=\mathrm{en} \& \mathrm{mt}=11$.

Lechner, C. and Dowling, M. (2003), "Firm networks: external relationships as sources for the growth and competitiveness of entrepreneurial firms", Entrepreneurship and Regional Development, Vol. 15 No. 1, pp. 1-26.

Lechner, C. and Leyronas, C. (2012), "The competitive advantage of cluster firms: the priority of regional network position over extra-regional networks - a study of a French high-tech cluster", Entrepreneurship and Regional Development, Vol. 24 Nos 5-6, pp. 457-473.

Lerner, J. (2020), Government Incentives for Entrepreneurship (No. w26884), National Bureau of Economic Research, Cambrdige, MA.

Littunen, H. and Niittykangas, H. (2010), "The rapid growth of young firms during various stages of entrepreneurship", Journal of Small Business and Enterprise Development, Vol. 17 No. 1, pp. 8-31.

Lorenzoni, G. and Lipparini, A. (1999), "The leveraging of interfirm relationships as a distinctive organizational capability: a longitudinal study", Strategic Management Journal, Vol. 20 No. 4, pp. 317-338.

Mack, E. and Mayer, H. (2016), "The evolutionary dynamics of entrepreneurial ecosystems”, Urban Studies, Vol. 53 No. 10, pp. 2118-2133. 
$\mathrm{MD}$

59,13

Mason, C. and Brown, R. (2013), Entrepreneurial Ecosystems and Growth Oriented Entrepreneurship, Paper Presented at the Workshop organised by the OECD LEED, Programme and the Dutch Ministry of Economic Affairs, The Hague.

Mattes, J. (2012), "Dimensions of proximity and knowledge bases: innovation between spatial and nonspatial factors”, Regional Studies, Vol. 46 No. 8, pp. 1085-1099.

Meza, X.V. and Park, H.W. (2016), "Organic products in Mexico and South Korea on Twitter", Journal of Business Ethics, Vol. 135 No. 3, pp. 587-603.

Motoyama, Y. and Knowlton, K. (2017), "Examining the connections within the startup ecosystem: a case study of st. Louis", Entrepreneurship Research Journal, Vol. 7 No. 1, pp. 1-32, 20160011.

Nambisan, S. (2017), "Digital entrepreneurship: toward a digital technology perspective of entrepreneurship", Entrepreneurship Theory and Practice, Vol. 41 No. 6, pp. 1029-1055.

Nambisan, S. and Baron, R.A. (2013), "Entrepreneurship in innovation ecosystems: entrepreneurs' selfregulatory processes and their implications for new venture success", Entrepreneurship: Theory and Practice, Vol. 37 No. 5, pp. 1071-1097.

Nylund, P. and Cohen, B. (2017), "Collision density: driving growth in urban entrepreneurial ecosystems", International Entrepreneurship and Management Journal, Vol. 13 No. 3, pp. 757-776.

Pitelis, C. (2012), "Clusters, entrepreneurial ecosystem co-creation, and appropriability: a conceptual framework", Industrial and Corporate Change, Vol. 21 No. 6, pp. 1359-1388.

Presutti, M., Boari, C. and Majocchi, A. (2013), "Inter-organizational geographical proximity and local start-ups' knowledge acquisition: a contingency approach”, Entrepreneurship and Regional Development, Vol. 25 Nos 5-6, pp. 446-467.

Raisi, H., Baggio, R., Barratt-Pugh, L. and Willson, G. (2018), "Hyperlink network analysis of a tourism destination", Journal of Travel Research, Vol. 57 No. 5, pp. 671-686.

Rioux, P. (2020), Un indice pour la French Tech Toulouse, La Dépêche du Midi, Toulouse.

Rogers, R. (2013), Digital Methods, MIT Press, Cambridge, MA.

Roundy, P.T., Brockman, B.K. and Bradshaw, M. (2017), "The resilience of entrepreneurial ecosystems", Journal of Business Venturing Insights, Vol. 8, pp. 99-104.

Scaringella, L. and Radziwon, A. (2018), "Innovation, entrepreneurial, knowledge, and business ecosystems: old wine in new bottles?”, Technological Forecasting and Social Change, Vol. 136, pp. 59-87.

Scheidgen, K. (2021), "Degrees of integration: how a fragmented entrepreneurial ecosystem promotes different types of entrepreneurs", Entrepreneurship and Regional Development, Vol. 33 Nos 1-2, pp. 54-79.

Semrau, T. and Werner, A. (2014), "How exactly do network relationships pay off? The effects of network size and relationship quality on access to start-up resources", Entrepreneurship Theory and Practice, Vol. 38 No. 3, pp. 501-525.

Shore, J., Baek, J. and Dellarocas, C. (2018), "Network structure and patterns of information diversity in twitter", MIS Quarterly, Vol. 42 No. 3, pp. 849-872.

Sorenson, O. and Stuart, T.E. (2001), "Syndication networks and the spatial distribution of venture capital investments", American Journal of Sociology, Vol. 106 No. 6, pp. 1546-1588.

Spigel, B. (2017), "The relational organization of entrepreneurial ecosystems", Entrepreneurship Theory and Practice, Vol. 41 No. 1, pp. 49-72.

Spigel, B. and Harrison, R. (2018), "Toward a process theory of entrepreneurial ecosystems", Strategic Entrepreneurship Journal, Vol. 12 No. 1, pp. 151-168.

Stam, E. (2015), "Entrepreneurial ecosystems and regional policy: a sympathetic critique", European Planning Studies, Vol. 23 No. 9, pp. 1759-1769.

Stam, E. and Spigel, B. (2017), "Entrepreneurial ecosystems", in de Clercq, D., Heinonen, J. and Wang, Z. (Eds), Handbook for Entrepreneurship and Small Business, Sage, London, pp. 407-422. 
Täuscher, K. and Laudien, S.M. (2018), "Understanding platform business models: a mixed methods study of marketplaces”, European Management Journal, Vol. 36 No. 3, pp. 319-329.

Stam, E. and Van de Ven, A. (2021), "Entrepreneurial ecosystem elements", Small Business Economics, Vol. 56, pp. 809-832.

Tallman, S., Jenkins, M., Henry, N. and Pinch, S. (2004), "Knowledge, clusters, and competitive advantage", Academy of Management Review, Vol. 29 No. 2, pp. 258-271.

Teece, D.J. (2007), "Explicating dynamic capabilities: the nature and microfoundations of (sustainable) enterprise performance", Strategic Management Journal, Vol. 28 No. 13, pp. 1319-1350.

Start-ups in entrepreneurial ecosystems

Tegarden, L.F., Echols, A.E. and Hatfield, D.E. (2000), "The value of patience and start-up firms: a re-examination of entry timing for emerging markets", Entrepreneurship Theory and Practice, Vol. 24 No. 4, pp. 41-58.

Theodoraki, C., Messeghem, K. and Rice, M.P. (2018), "A social capital approach to the development of sustainable entrepreneurial ecosystems: an explorative study", Small Business Economics, Vol. 51 No. 1, pp. 153-170.

Thornton, P. and Fkynn, K.H. (2005), "Entrepreneurship, networks, and geographies", in Acs, Z. and Audretsch, D. (Eds), Handbook of Entrepreneurship Research, Springer Science, New York, pp. 401-436.

Torossian, C., Pellegrin, C. and Pauly, J. (2020), Baromètre: Attractivité des Métropoles Françaises et Dynamisme des Territoires, Arthur-Loyd, Paris.

Tsou, H.-T., Ja-Shen, C. and Ya-Wen, Y. (2019), "Antecedents of co-development and its effect on innovation performance", Management Decision, Vol. 57 No. 7, pp. 1609-1637.

Vapola, T.J. (2011), "The laws of attraction: what attracts innovative start-up firms to partnerships with global MNCs?”, Journal of International Entrepreneurship, Vol. 9 No. 1, pp. 39-61.

Vedula, S. and Kim, P.H. (2019), "Gimme shelter or fade away: the impact of regional entrepreneurial ecosystem quality on venture survival”, Industrial and Corporate Change, Vol. 28 No. 4, pp. $827-854$.

Voelker, T.A. (2012), "Entrepreneurial ecosystems: evolutionary paths or differentiated systems?", Business Studies Journal, Vol. 4, pp. 43-61.

Wickham, P. (2004), Strategic Entrepreneurship, 3rd ed., FT Prentice Hall, London.

Wincent, J. (2005), "Does size matter? A study of firm behavior and outcomes in strategic SME networks", Journal of Small Business and Enterprise Development, Vol. 12 No. 3, pp. 437-453.

Witt, P. (2004), "Entrepreneurs' networks and the success of start-ups", Entrepreneurship and Regional Development, Vol. 16 No. 5, pp. 391-412.

Woolley, J.L. and MacGregor, N. (2021), "The influence of incubator and accelerator participation on nanotechnology venture success", Entrepreneurship Theory and Practices, online first. doi: 10. 1177/10422587211024510.

Wurth, B., Stam, E. and Spigel, B. (2021), “Toward an entrepreneurial ecosystem research program”, Entrepreneurship Theory and Practice. doi: 10.1177/1042258721998948.

Zott, C. and Amit, R. (2007), "Business model design and the performance of entrepreneurial firms", Organization Science, Vol. 18 No. 2, pp. 181-199.

\section{Corresponding author}

Christian Lechner can be contacted at: clechner@luiss.it

For instructions on how to order reprints of this article, please visit our website:

www.emeraldgrouppublishing.com/licensing/reprints.htm

Or contact us for further details: permissions@emeraldinsight.com 